\title{
I, Easy Philosopher: Who is Andrew Marvell's Upon Appleton House Really About?
}

\author{
Bill Philips \\ University of Barcelona
}

\begin{abstract}
It is generally assumed that the poem is a tribute to General Fairfax and his house and family. While these are important to the poem, as well as weighty political and religious considerations of the time, I wish to argue that it is primarily about the poet himself. Biographical interpretations of Marvell's poetry have been discouraged by some critics but in the case of Upon Appleton House, with its unequivocal references to real people, including Andrew Marvell himself, a strong case can be made for such an interpretation.
\end{abstract}

It is easy to accuse poets of ego-mania. What else could bring them to expose their viscera to the public eye? Why do they imagine that the world is interested in their love affairs, sufferings and philosophisms or that their writing is of sufficient quality to deserve widespread consumption and withstand informed criticism? Virtually all poetry is about the poet despite the ostensible theme presented. Shakespeare, in the final lines of his celebrated eighteenth sonnet "Shall I compare thee to a summer's day," is praising his own ability as a writer to give beauty immortality, while implicitly criticising beauty's transience: "So long as men can breathe, or eyes can see,/So long lives this, and this gives life to thee"(1108) Indeed, this is a recurring theme in the sonnets. Other poets are less subtle about about their own vanity: it is typical of Sir John Suckling to boast: "Out upon it, I have lov'd,/Three whole days together;/And am like to love three more,/If it prove fair weather"(Gardener 180). Andrew Marvell, too must take his place in the dock: in his defence, little of his poetry was published in his life-time, but the charge remains that the poet's first concern is to him/herself.

In this essay I intend to discuss who Upon Appleton House (79-107) is really about. There are a number of candidates: Thomas Fairfax is the obvious first choice (as the dedication to the poem suggests), followed by his daughter, Mary, and then by a wider audience, for whom the poem is intended, perhaps, to be both instructive and entertaining. A final candidate is Marvell himself, who may have written the poem as the result of, or 
in order to resolve, some inner debate of his own. What, precisely, was the cause of that debate? How is it concluded? What evidence is there to support the assertion that Marvell was primarily concerned with his own life and future in Upon Appleton House? The strongest evidence that the poem centres on Thomas Fairfax comes from the title: Upon Appleton House/To my Lord Fairfax. Nevertheless, there is no immutable law that says that a poem must be about the person it is dedicated to. The poem is quite clearly about Appleton House; its grounds, inhabitants and history are used as a vehicle for Marvell's musings and observations, and since the house belongs to Fairfax, it seems only polite to dedicate the poem to him. This politeness should not be mistaken for sycophancy. The country house poem genre was traditionally a means by which a great house, and by association its master, was praised. This genre had classical origins which were taken up by such English writers as Ben Jonson with "To Penshurst" and was employed by Marvell who seemed to prefer to make use of traditional forms in his poetry rather than in developing anything new. This does not mean that he uses traditional forms in traditional ways; he was not Fairfax's court jester and it would be uncharacteristic of him to write a clever poem that was merely designed to compliment his employer. In fact, very little of the poem is directly about Thomas Fairfax. Stanzas 5 to 10 allude to Fairfax's greatness, though it is the greatness of the family line which seems to be receiving as much of the praise as Thomas himself: "And surely when the after age/Shall hither come in pilgrimage,/These sacred places to adore,/By Vere and Fairfax trod before" (vv. 33-36). Stanzas 36 to 43 continue to praise the House of Fairfax, and now it is the gardens rather than the house which are singled out, but which Fairfax it was that actually laid them out is not clear. It is not until stanzas 44 to 46 that we can be reasonably sure it is Thomas Fairfax who is being discussed.

And yet there walks one on the sod

Who had it pleased him and God,

Might once have made our gardens spring

Fresh as his own and flourishing.

But he preferred to the Cinque Ports

These five imaginary forts,

And, in those half-dry trenches spanned

Power which the ocean might command.

For he did with his utmost skill, Ambition weed, but conscience till Conscience, that heaven-nursed plant, Which most our earthy gardens want.

(XLIV-XLV 345-56)

Marvell focusses on might-have-beens and reserves his praise for Fairfax's skill in tilling his conscience: surely there is some irony here. There are few other references to Thomas Fairfax: in stanza 59 we see Denton, “jealous of its Lord's long stay,/It tries t'invite him thus away” and in stanza 93 Marvell anticipates Maria Fairfax's wedding and the rejoicing 
of her parents: "The priest shall cut the sacred bud,/While her glad parents most rejoice." (LXXXXIII 742-43).

Maria Fairfax receives far more attention than her father; stanzas 82 to 95 are exclusively about her. Marvell seems to have a propensity for writing about little girls; "The Picture of little T. C. in a prospect of Flowers" is another example. In both poems he sees the girls as paradigms representing all hope, innocence and perfection:

She that already is the law

Of all her sex, her age's awe.

See how loose Nature, in respect

To her, itself doth recollect;

And everything so whisht and fine,

Starts forthwith to its bonne mine.

The sun himself, of her aware,

Seems to descend with greater care;

And lest she see him go to bed,

In blushing clouds conceals his head.

(LXXXII-LXXXIII 655-64)

She is obviously important, being the Fairfax's only child and direct heir and, at her age symbolizes innocence, and thus, in the concluding section of the poem, represents what hope there is for the future. Moreover, Marvell is employed by Thomas Fairfax as Maria's tutor and is not afraid of making use of the poem to inform his employer of his pedagogical success:

For she to higher beauties raised,

Disdains to be for lesser praised.

She counts her beauty to converse

In all the languages as hers;

Nor yet in those herself employs

But for the wisdom, not the noise;

Nor yet that wisdom would affect,

But as 'tis heaven's dialect.

(LXXXIX 705-13)

If we assume that the poem was to be read by all the Fairfax family, then we can recognise parts which were written for his young pupil's amusement:

Let others tell the paradox, How eels now bellow in the ox;

How horses at their tails do kick,

Turned as they hang to leeches quick;

How boats can over bridges sail; 
And fishes do the stables scale.

How salmons trespassing are found;

And pikes are taken in the pound.

(LX 473-81)

This stanza is a mixture of wordplay and riddle. There is clearly a pun in fishes scaling the stables, a joke in the idea of salmon trespassing rather than poachers trespassing in search of salmon and perhaps a riddling reference to the Bosphorus in the second line. The grasshopper stanza can be seen in a similar light; it has a sense of the ridiculous to appeal to a child as well as presenting the scene from a child's eyes:

And now to the abyss I pass

Of that unfathomable grass,

Where men like grasshoppers appear,

But grasshoppers are giants there:

They, in their squeaking laugh, contemn

Us as we walk more low than them:

And, from the precipices tall

Of the green spires, to us do call.

(XLVII 369-76)

A. Alvarez describes this passage as a conceit, though not in the metaphysical style: It is instead, nearer the wit of Lewis Carroll (112). It is also a nightmare vision of an anarchic world where the hierarchy of power has been inverted; grasshoppers were traditionally represented as social creatures reflecting the harmonious nature of society. Suddenly they become ominously large and unnaturally mocking. Marvell's fears about the danger to society that the Levellers represent is revealed later in the poem. We do not know exactly what Marvell's feelings were towards Maria. She married the Duke of Buckingham in 1657, and according to stanza 90 had already withstood a number of romantic sieges: "Blest Nymph! that couldst so soon prevent/Those trains by youth against thee meant" (LXXXX 713-14). It is unlikely that Marvell ever contemplated presenting himself as a suitor. It seems unlikely, firstly because tutors did not marry their pupils and secondly Marvell presumably had too much affection and respect for the Fairfax family to attempt any kind of illicit liaison. Consequently, although Maria is fulsomely praised in the poem, I think that Marvell is trying to amuse rather than court her, while, at the same time, flattering her parents.

There are a number of themes in the poem which could, arguably, have been included for the benefit of (limited) public consumption. The description of the house, along with William Fairfax's rescue of Isabel Thwaites and the conversion of the nunnery to the Fairfax family seat are presentations of Marvell's religious and political beliefs:

But he, superfluously spread,

Demands more room alive than dead; 
And in his hollow palace goes

Where winds (as he) themselves they lose;

What need of all this marble crust

T'impark the wanton mote of dust,

That thinks by breadth the world t'unite

Though the first builders failed in height?

(III 17-24)

Appleton House's lack of grandeur is in contrast to the excessive size and ornamentation of other, less modest buildings. This is a clear reference to the Catholic church, with its gilded, pompous palaces which have spread throughout the world but never get close to God. In Appleton House, in honest protestant fashion, "all things are composed here/Like Nature, orderly and near" (IV 25-26). The attack on Catholicism at the beginning of the poem, when William Fairfax rescues Isabel Thwaites from the decadent clutches of the nuns is clearly a standard, if rather predictable piece of puritan propaganda. The house does not become truly religious until the nuns are removed and William and Isabel installed, consecrating the building, presumably, with the purity of their hearts: "'Twas no religious house till now" (XXXV 280). Further on Marvell glorifies England in a stanza reminiscent of John of Gaunt's speech in Richard II (II.I):

Oh thou, that dear and happy isle

The garden of the world ere while, Thou paradise of four seas,

(XXXXI 321-23)

Having declared his loyalties to religion and patriotism Marvell moves on to recount his country's problems with reference to the Levellers and the danger of social breakdown in stanzas XXXXII-LVIII. Despite opposition to King Charles I, and support for the republic, few of those on the Parliament side wanted to see an end to the landowning classes. Fairfax did not fight the Civil War to have his lands taken away from him, and Marvell clearly believes in the value of exemplary families like the Fairfaxes, and their hereditary right to their extensive properties. This is apparent not only in his defence of the way Appleton House came into Fairfax hands or the sense of destiny embodied by Maria but also, later in the poem, with an attack on the Levellers. Fairfax, of course, is kind to the commoners - he has not enclosed his land for his own exclusive use:

This scene again withdrawing brings

A new and empty face of things,

A levelled space, as smooth and plain

As cloths for Lely stretched to stain.

The world when first created sure

Was such a table rase and pure. 
Or rather such is the toril

Ere the bulls enter at Madril.

For to this naked equal flat,

Which Levellers take pattern at,

The villagers in common chase

Their cattle, which it closer rase;

And what below the scythe increased

Is pinched yet nearer by the beast.

Such, in the painted world, appeared

D'Avenant with the universal herd.

(LVI-LVII 441-56)

With Fairfax at least, the commoners can have no complaint, and so the intentions of the Levellers are meaningless. Politically, Marvell is reflecting Cromwell's attitude to them: they are a threat that must be controlled, if not wiped out. Marvell is in that peculiar position of being neither a member of the aristocracy (he depends on their patronage) nor a rustic commoner. He is extremely well-educated, cultured and intelligent so it is perhaps not surprising that he looks down on the commoners with distaste. It seems far more likely that Fairfax would have had "the common touch" as his popularity as a general shows, while Marvell was probably something of a snob. He has no kind words for the hardworking villagers; they are "fleas" (LVIII 461), the villagers' cattle are referred to as "the beast" (LVII 454) with its satanic as well as common herd connotations and the grass "Is pinched yet nearer" (LVII 454) denoting the meanness of the people. Presumably such meanness would have been unnecessary if the villagers had had more meadows at their disposal. There is a suggestion, too, that it is the common people who are responsible for the bloodshed of the Civil War. They were the foot soldiers wielding pikes, cudgels and knives who "massacre the grass along" (L 394). The killing of the rail could represent the execution of Charles I: "While one, unknowing, carves the rail,/Whose yet uncovered quills her fail" (L 395-396). If so, it recalls the "armed Bands" who "clap their bloody hands" in "An Horatian Ode upon Cromwel's Return from Ireland" (55-56). Thus Marvell removes the blame for the sin of murder from Fairfax, Cromwell and other military and aristocratic leaders and places it on the common people without losing the opportunity to relieve himself of a little spite.

Yet not Fairfax, not Maria, nor political nor moral lessons are presented at the beginning of the poem. It is the house and its architect which appear in the first two lines: "Within this sober frame expect/Work of no foreign architect," (I 1-2) However, "This sober frame" is not only the house but the poem as well. It seems as reasonable to apply the word "frame" to a poem as to a building especially when a poem is as carefully constructed as Upon Appleton House. It is also "sober": although, as we have seen, there are lighthearted, witty parts to the poem, it is far more serious, reflective and ambitious than much of Marvell's other poetry such as "To his Coy Mistress," "The Nymph Complaining for the Death of Her Faun" or "The Garden." The architect is the poet, and like the house, which was built from the ruins of a nunnery (building implies cleansing 
here), there is no foreign taint in either the work or its creator. The nunnery, of course, was Catholic, subject to the foreign power of Rome but with the dissolution of the monasteries this foreign influence disappeared and Appleton House became wholly English. Marvell, too, may have flirted with, if not converted to Catholicism in 1639 , only to be rescued by his father. He also travelled widely in Europe during his twenties, including to those most Catholic of countries, Spain and Italy; by the time he comes to write Upon Appleton House he wants to assure us of his impeccable Englishness and Protestantism.

It seems probable that he at least partly financed his European travels with the money he inherited when his father died in 1641 and so in about 1650 , needing to earn a living, he moved to Appleton House to become Maria Fairfax's tutor.He would have been almost thirty when he arrived there, at an age when he would have sown the wild oats celebrated in "To his Coy Mistress" and begun to think seriously about his future and what he could usefully do with his life. He knew he was talented and, although not a man with any military genius like Fairfax or Cromwell, he had other abilities and a cause and beliefs to dedicate them to. The debate about a life of action or retirement in the poem, generally assumed to apply to Fairfax, applies equally, if not more so to Marvell himself. Fairfax was not a young man in 1650, and having led numerous successful campaigns in the Civil War would seem to be quite justified in retiring to the comfort and responsibilities of his estate and family. Marvell, however, at the age of thirty, without any great achievements behind him, finds himself sharing Fairfax's retirement in the position of tutor to Fairfax's daughter. The fact that Maria Fairfax must soon become too old to need a tutor may well have contributed to Marvell's dilemma, but clearly the position of personal tutor to other Maria Fairfaxes was always an option; he would have been well-recommended (in 1653 Marvell did, in fact, become tutor to William Dutton, a protégé of Cromwell's). The prospect of a life of rural comfort and monotony, however delightful it at first appears, cannot have been fulfilling to a man of Marvell's energies and this, I believe, is what he is debating in Upon Appleton House. In 1657 Marvell was appointed Latin Secretary to the Council of State and from 1659 to the end of his life in 1678 he was MP for Hull. His political career is proof that at some time he decided that a quiet life as a country tutor was not for him. That he did not begin his political career before 1657 may simply be due to lack of opportunity, though in hindsight, his tutorship of William Dutton could be interpreted as a career move.

Marvell returns to the poet in stanza 61: "But I, retiring from the flood,/Take sanctuary in the wood" (LXI 481-482). As the use of the pronoun "I" shows, it is not Fairfax here, contemplating retirement, but the poet, who can be none other than Marvell himself. In the next twenty stanzas Marvell describes in georgic fashion the beauties of nature and huasbandry. The security offered by the house of Fairfax is reflected by the ancient trees in the wood: "The double wood of ancient stocks,/Linked in so thick, an union locks" (XVII 489-490). Beauty, art, comfort and morality are all here, providing everything, apparently, that a poet could want. So tempting does this world appear that Marvell asks, in stanza 77, to be restrained by the forces of Nature from abandoning it:

Bind me, ye woodbines, in your twines, Curl me about, ye gadding vines, 
And, oh, so close your circles lace,

That I may never leave this place:

(LXXVII 609-12)

The fact that Marvell writes these lines reveals the conflict in his mind. If this world is such a paradise then why does he even contemplate leaving it? Indeed, it is more than just the temptation to leave that disturbs him; he needs holding down to keep him there! He is not ready for Paradise yet. This may explain the suggestion of crucifixion in the second half of the stanza; only physical restraint would convince him that he was truly about his Father's business:

But lest your fetters prove too weak,
Ere I your silken bondage break,
Do you, O brambles, chain me too,
And, courteous briars, nail me through.

(LXXVII 613-16)

By the end of the poem Marvell recognises the necessity of balancing the active world with the contemplative. Appleton House may be "heaven's centre, Nature's lap/And paradise's only map" (LXXXXVI 767-68), but in the last stanza the "salmon fishers" (LXXXXVII 769) summon him to the real world and like "rational amphibii" (LXXXXVII 774) he must move on.

The number of times that Thomas Fairfax, Maria and Marvell are referred to in the poem helps to show us the importance the poet gave to each. The name Fairfax is mentioned eight times. It also appears in the dedication and as the adjective Fairfacian. However, only four of these directly refer to Thomas Fairfax himself, the others referring to William Fairfax or the Fairfax family. From a total of sixty masculine personal pronouns in the poem only eleven refer to Thomas Fairfax, seventeen to William and nearly all of the rest to the woodpecker. Maria is mentioned by name twice. From a total of fifty-nine feminine personal pronouns thirty-six refer to Maria. The rest are shared by Isabel Thwaites, Nature, nuns and others. Marvell does not mention himself by name at all, but refers to himself once as "philosopher" (LXXI 561). From a total of fifty-three first person personal pronouns forty-six refer to the poet, the others are spoken by the nuns and William Fairfax. The individual who receives the greatest number of references in the poem is the poet, Maria gains a respectable second place but Thomas Fairfax does very poorly with his final total of fifteen.

With the exception of Augustine's Confessions and Saint Teresa's Life of Herself it is Jean-Jacques Rousseau who is credited as being first to write about his own life in his Confessions, first published in 1781; indeed the first lines of the work declare: "I have resolved on an enterprise which has no precedent, and which once complete, will have no imitator" (17). Rousseau's second claim is well wide of the mark, but he was hardly to know that. The first is more justifiable, especially for the detail, worldliness and audacity 
of the Confessions. Nevertheless, apart from the works of Augustine and Saint Teresa there are many examples of autobiographical fragments and a multitude of texts displaying the internal conflicts and torments suffered by their authors which were written before Rousseau's Confessions. Such conflicts are common in the poetry of George Herbert. His "Affliction" is an account of the mental vicissitudes that a life of service to God brings; "The Collar" describes his desire to be free from the servitude of religion: to be able to do as he pleases: "My lines and life are free; free as the rode,/Loose as the winde, as large as store" (Gardner 135). John Donne, in Biathanatos discusses the question of suicide. Despite (or, as he says, because of) his Roman Catholic origins Donne describes his sympathy for the suicide, concluding the work with the assertion that Jesus effectively committed suicide. But it is in the preface to the work that we learn of the reason for Donne's interest in the matter: "[W]hensoever any affliction assailes me, mee thinks I have the Keyes of my prison in mine owne hand, and no remedy presents it selfe so soone to my heart, as mine own sword" (61). This is indisputably autobiographical and confessional, so much so that Donne asked for it not to be published, yet not destroyed either: "Reserve it for me, if I live, and if I die, I only forbid it the Presse, and the Fire: publish it not, but yet burn it not; and between those, do what you will with it" (Simpson 160). Upon Appleton House, though neither confessional nor autobiographical in the way that Rousseau's Confessions is, nor the product of internal religious conflict in the style of Herbert and Donne, can be grouped, nevertheless, with the latter, not only for historical reasons, but also because of the particular nature of Marvell's concerns. He is not laying the whole of his life bare, simply one part at a certain time in his life, just as Donne is when he describes Biathanos as "a Book written by Jack Donne. and not D. Donne" (Simpson 160).

Sir Frank Kermode argues against reading Marvell's poetry as autobiography. Writing about "The Garden" he says: "What was Marvell's state of mind as he wandered in Fairfax's Yorkshire garden?" is a very bad question to ask, but it is obviously one which comes readily to the minds of learned and subtle interpreters; both Marvell and Donne have suffered greatly from this form of misapplied scholarship, and it is comforting to reflect that the date of "The Garden" is quite unknown, so that it cannot be positively stated to be the direct record of some personal experience at Nun Appleton. It could conceivably have been written much later (200). An important difference between "The Garden" and Upon Appleton House is that, while the former refers to no specific person, place or event the second clearly does. It also seems perfectly reasonable to assume that the $I$ in the poem is Marvell and not an adopted persona. Furthermore, the exact date when the poems were written is of no importance. There is no reason why they could not have been written years later, perhaps nostalgically, in memory of more youthful events and internal debates. I, personally, would propose that Marvell wrote Upon Appleton House for Maria Fairfax's wedding to the Duke of Buckingham in 1657 since this neatly explains the hagiography of Maria in the poem as well as the careful exposition of Marvell's political credentials to Buckingham with whom his future parliamentary alignment lies.

If Upon Appleton House is about any single individual then that individual is Marvell. Apart from the overwhelming evidence of the pronoun count, it can be seen that the subject matter is Marvell's. He is expounding his beliefs and debating his own future: 
whether this is done in retrospect or not does not affect the centrality of himself to the poem. The debate was resolved at some stage and Marvell left the garden for an active public life.

\section{Works Cited}

Alvarez, A. The School of Donne. London: Chatto and Windus, 1970.

Donne, J. Selected Prose. Ed. N. Rhodes. London: Penguin, 1987.

Gardner, H., ed. The Metaphysical Poets. London: Penguin, 1979.

Kermode, F. The Arguments of The Garden. London: Macmillan, 1980.

Marvell, A. The Poems of Andrew Marvell. Ed. H. MacDonald. London: Routledge and Kegan Paul, 1972.

Shakespeare, William. The Complete Works. London: Oxford UP, 1957.

Simpson, Evelyn M. A Study of the Prose Works of John Donne. Oxford: Oxford UP, 1948. 